\title{
MANAGEMENT OF CARCINOMA BLADDER: A REVIEW LITERATURE
}

\author{
Gurinderjit Singh Nagi ${ }^{1}$, Yatin Ghosh ${ }^{2}$
}

\section{HOW TO CITE THIS ARTICLE:}

Gurinderjit Singh Nagi, Yatin Ghosh. "Management of Carcinoma Bladder: A Review Literature". Journal of Evolution of Medical and Dental Sciences 2015; Vol.4, Issue 01, January 01; Page: 95-111,

DOI:10.14260/jemds/2015/15

\begin{abstract}
Carcinoma of the bladder is a disease of the elderly. Bladder cancer is three times more common in males than in females and more common in whites than in blacks. Patients with bladder cancer have a $1 \%$ to $4 \%$ incidence of synchronous or metachronous upper tract urothelial tumors. There are many risk factors for urothelial cancer, classified into (1) Genetic (2) chemical exposure, and (3) chronic irritation. Genetic abnormalities associated with CIS include alterations in the retinoblastoma gene (Rb), p53, and PTEN. Chemical exposure has the most epidemiologic evidence to support it as an inciting agent (Aromatic amines, aniline dyes, and nitrites and nitrates). Chronic irritants include catheters, recurrent urinary track infections, Schistosoma haematobium, and irradiation. There are many studies that suggest high water consumption, vitamin intake, and various diets that are beneficial in preventing bladder cancer. However, none of these have shown any clear benefit with respect to prevention.
\end{abstract}

KEYWORDS: cancer, chemical, Chronic irritation, genetic material, males, urothelial, cancer.

INTRODUCTION: OVERVIEW: Like all malignancies, carcinoma of the bladder arises from aberration of normal mechanisms governing cell differentiation and proliferation. Essentially a disease of elderly, bladder cancer results from the induction of oncogenes or the negation of tumor suppressor genes resulting in a malignantly transformed cell. Formerly called transitional cell carcinoma, the most common type of bladder cancer is urothelial carcinoma. Exposure of host cells to certain viruses, chemical carcinogens, and chemical/physical stimuli play a dominant role in the carcinogenesis of bladder cancer.

Urothelial cancer has been characteristically defined as a field change disease in which entire urothelium of the renal pelvis to the urethra is susceptible to malignant transformation. These urothelial carcinoma cells can also implant and probably migrate to other sites of the urothelium, thus making it difficult to determine whether a recurrent tumor represents an inadequately treated initial tumor, tumor implantation/migration, or the effects of multifocal carcinogenesis.

EPIDEMIOLOGY: Bladder cancer is three times more common in men than in women.(1) Described as fourth most common cancer in men after prostate, lung and colorectal cancer, and the ninth most common cancer in women.(1) Bladder cancer is a disease of older individuals with greater than $90 \%$ of diagnosis in patients more than 55 years of age;although uncommon bladder cancer can occur in young adults and even in children.(2) The incidence of bladder cancer has been gradually increasing by approximately $40 \%$ according to the National Cancer Institute's Surveillance Epidemiology and End Results (SEER) Registry.(3) In united States an over-all risk of developing bladder cancer is approximately 1 in 28. $(4,5)$ 
ETIOLOGY: The etiology of bladder cancer appears to be multifactorial with exogenous environmental factors, as well as endogenous molecular factors playing. The link between bladder cancer and environmental carcinogen has long been observed.(6) Factors related to bladder cancer's development and progression include occupational exposure to chemicals; cigarette smoking; coffee drinking; ingestion of analgesics or artificial sweeteners; bacterial parasitic, fungal and viral infections: harboring of bladder calculi, and receiving genotoxic chemotherapeutic agents.

Molecular instabilities and abnormal metabolic pathways may likewise play a role in BC development and progression. Pathways involved in altered chemical metabolism of exogenous carcinogens have included aberrant cytochrome P450 metabolism(Associated genetic defects), glutathione-s-transferase abnormalities, and $\mathrm{N}$-acetyltransferase genetic and metabolic derangements. $(7,8,9,10)$ Genetic instability may result in abnormal activity of oncogenes resulting in aberrant protein expression, cellular proliferation and resistance to apoptosis. ${ }^{(10,11)}$

Tumor suppressor genes abnormalities associated with BC include p53, p21, p16 and $\mathrm{Rb}$ (retinoblastoma) tumor suppressor genes that may have mutated or inactivated and such defects may thereby predispose to cell dysregulation and tumor cell development and progression.(12-15) Increasing evidence suggests that genetic predisposition has a significant influence on BC incidence especially via its impact on susceptibility to other risk factors. ${ }^{(16,17)}$

Tobacco smoking is the most important risk factor for BC, amounting for $50 \%$ of cases.(16,18) Tobacco smoke contains aromatic amines and polycyclic aromatic hydrocarbons which are renally excreted.

Occupational exposure to aromatic amines, policyclic aromatic hydrocarbons and chlorinated hydrocarbons is the second most important risk factor for BC and such occupational exposure occurs mainly in industrial branches processing paint, dye, metal and petroleum products.(16,19-21) Exposure to arsenic in drinking water increases BC risk.(16,22) It is suggested that cyclophosphamide and pioglitazone are weakly associated with BC risk.(16) Schistosomiasis is a cause of BC particularly SCC.(16)

PATHOLOGY OF CARCINOMA BLADDER: Bladder urothelium is lined by transitional cells that can transform into a variety of malignant tumors. Understanding the pathology of urothelial carcinoma is critical in determining prognosis, as the most important risk factor for progression is tumor grade rather than stage.(23) Up to $80 \%$ of urothelial tumors are non-muscle invasive at presentation and can include papillary urothelial neoplasm of low Specific malignant potential (PUNLMP), CIS, and lowand high-grade urothelial cancers. Muscle-invasive bladder cancer is by definition high grade, with the majority spreading via direct extension from surface urothelial carcinoma through the subepithelial connective tissue into the muscularispropria. PUNLMP has minimal cytologicatypia and has very little invasive or metastatic potential but recurrence is seen after resection. $(24,25)$

CIS is characterized by higher rates of progression and is a flat, high-grade tumor within the superficial epithelium.(23) CIS represents high-grade disease and is associated with genetic alterations that are similar to those found in other high-grade urothelial subtypes. CIS is characterized by a reddish, velvety appearance and can often be mistaken for the edematous changes of radiation cystitis. Despite its unassuming name, CIS can progress to invasive disease and also demonstrate pagetoid spread to the ureters and prostatic urethra in some cases.(26) Genetic abnormalities are different from high-grade lesions and most commonly include deletion of 9q.(27) Higher progression and mortality rates are noted with high-grade disease, believed to be secondary to genetic 
abnormalities distinct from low-grade lesions, which confer the ability to invade the underlying stroma. High-grade tumors are composed of fused papillary stalks with undifferentiated cancer in the urothelial layer. Transitional cell carcinoma is the most common subtype and is present in over $90 \%$ of tumors. ${ }^{(28)}$

CLINICAL PRESENTATION, DIAGNOSIS AND EVALUATION: The most common presenting symptom of bladder cancer is painless hematuria which occurs in majority of patients, is continuous or intermittent and gross or microscopic. From microscopic hematuria screening studies, it has been estimated that $1.3 \%$ of patients will have underlying diagnosis of $\mathrm{BC}$ although it is more likely in patients with gross hematuria. ${ }^{(29,30,31)}$ All patients with hematuria, particularly those without evidence of infection, stone or other causative factors should undergo cystoscopy and upper tract imaging. ${ }^{(32,33)}$ Irritative voiding symptoms including frequency, urgency and dysuria are particularly associated with carcinoma in situ. Indeed the diagnosis of $\mathrm{BC}$ is a consideration in patients with irritative voiding symptoms in the absence of infection. (AUA February 12, 2014).

BIMANUAL EXAMINATION: The physical examination of patients with bladder cancer is often unremarkable especially in case of non- muscle invasive disease. A bimanual exam at the time of TURBT may help with clinical staging especially for patients with muscle invasive disease. (AUA February 12, 2114).

URINARY CYTOLOGY: It is important to examine the specimens of urine or bladder- washings for cancer cells as this has high sensitivity in high grade tumors but low sensitivity in low grade tumors. The sensitivity of cytology in CIS ranges from 28 to 100\%.(34) The interpretation of cytology is user dependent ${ }^{(35)}$ and evaluation is effected by UTI, low cellular content or calculi; specificity may be even $90 \%$ in good hands hands. ${ }^{(36)}$

URINARY MARKER TESTS: For being a good bladder cancer marker, the test should be technically simple, of low cost, with good reliability, with high specificity and should be able to detect cancer before it escapes curative treatment.(36) There are numerous urinary tests for detection of bladder cancer.(36-42) The recently investigated tests markers include Quanticyt, BLCA-4, Hyaluronic acid, telomerase, Lewis X blood group antigens, microsatellite polymorphism analysis, cyto-keratins and surviving. ${ }^{(43,44)}$ Other tests are BTA stat test, BTA trak test, Nuclear matrix protein (NMP) 22, Immunocyt and UroVysion. Urinary marker tests detect less than half of the low grade tumors that are detected by cystoscopy.(39,42) The quality of follow-up cystoscopy can be impoved by the knowledge of positive test results (microsatellite analysis). ${ }^{(45)}$

IMAGING: The various imaging techniques are intravenous urography, computed tomography, MRI and ultrasonography. IVP will show filling defects but there is low incidence of significant findings with this method. ${ }^{46,47,48)}$ Computed tomography is used as an alternative method of investigation in some hospitals instead of intravenous urography.(49) In muscle invasive bladder tumors, Ct urography gives more information than IVU including the status of lymph nodes and adjacent organs.

CYSTOSCOPY AND FLUORESCENT CYSTOSCOPY: The diagnosis of papillary bladder carcinoma depends on cystoscopy examination and histological examination of the tissue. CIS is diagnosed by 
cystoscopy, urine cytology and HPE of multiple biopsies.(50) Flexible instrument with local anesthesia will allow better compliance. (51) If tumor has been visualized previously diagnostic cystoscopy may be omitted.(52) Fluorescent cystoscopy has been investigated to increase the detection of occult papillary lesions and CIS. Intravesical instillation with 5-aminolevulinic acid (5-ALA) is done which enhances the protoporphyrin IX visualization through uptake by cancerous cells. With blue light protoporphyrin IX becomes readily visible with an appropriate filter on the cystoscopy.(53) Improved detection may increase tumor detection rate and facilitate eradication and there by lower recurrence rate. ${ }^{(54,55)} 5$-ALA enhanced cystoscopy appears to improve sensitivity in detecting NMIBT. $(53,56)$

TRANSURETHELIAL RESECTION: The diagnosis of bladder carcinoma is made after TUR of the bladder lesion.(57) While tumor is resected at the time of TUR, it provides deep enough resection and biopsy to determine the depth of invasion for adequate staging information. ${ }^{(58)}$

PROGNOSTIC INDICATORS: The most important prognostic indicator with regard to the disease recurrence and progression has long been the tumor grade. ${ }^{(59,60,61)} \mathrm{A}$ revised consensus classification has been given by members of WHO and international society of urologic pathologists published in 2004.(62) Also other features with prognostic significance as regards to disease recurrence are tumor multiplicity and tumor size.(63,64) $\mathrm{T} 1$ tumors histologically portend disease recurrence, response to therapy and progression.(65-69) A number of molecular markers with regard to their ability to predict disease recurrence, response to therapy and progression include Lewis antigen, flow cytometry, tumor suppressor gene p53 and Rb, epidermal growth factor, CD44,matrix metalloproyeinses and urinary plasminogen activator. $(44,70,71)$

MANAGEMENT OF NON MUSCLE INVASIVE BLADDER TUMORS: Approximately $70 \%$ of bladder tumors are non- muscle invasive at presentation out of which $70 \%$ present $t$ as stage Ta. Recurrence is common in all patients with non-muscle invasive urothelial cancer but can often be controlled successfully with transurethral surgery, intravesical therapy or a combination.

TURBT: Under regional or general anesthesia is the initial treatment for most of the non-muscle invasive bladder carcinoma. A careful cystoscopy examination of the bladder and urethra should be done before TUR.(72) Small tumors less than $1 \mathrm{~cm}$ can be resected en block while larger tumors should be resected in fractions including the exophytic part of the tumor, the underlying bladder wall and the edges of the resection area. This approach will provide good information about vertical and horizontal extent of the tumor and helps to improve the completeness of resection.(73) Complete and correct resection is essential for good prognosis ${ }^{(74)}$ and absence of detrusor muscle in the specimen is associated with higher risk of residual disease and early recurrence. ${ }^{75)}$ After removal of all visible tumors, adjuvant intravesical immunotherapy or chemotherapy can be used.(76) Compared to mono polar resection, bipolar electro- cautery system may reduce the risk of complications eg., bladder perforation due to obturator nerve stimulation.(77)

OFFICE BASED FULGRATION/ENDOSCOPIC MANAGEMENT: Patients with a history of small, low grade recurrence can be managed in the office setting/OPD using diathermy or laser ablation under intravesical local anaesthesia.(78) 
BLADDER AND PROSTATIC URETHRA BIOPSIES: The risk of prostatic urethra and ducts' involvement is higher if tumor is on trigone or bladder neck in the presence of bladder CIS and multiple tumors. ${ }^{79,80)}$ So when bladder CIS is suspected, or cytology is positive with no evidence of bladder tumor, or abnormalities of prostatic urethra are visible, prostatic urethral biopsies are recommended.(81)

REPEAT TURBT: Complete tumor resection not always be possible due to excessive tumor volume, anatomic inaccessibility, medical instability requiring premature cessation or risk of perforation. A second TURB should be done after incomplete initial TUR, if there was no muscle in the first specimen, in all T1 tumors and all G3 tumors except primary CIS. If equipment is available, flourescence guided biopsy should be performed instead of random biopsies when bladder CIS or high grade tumor is suspected. Second TURBT can increase the recurrence-free survival.(82,83)

ADJUVANT THERAPY: The high variability in the three month recurrence rate indicates that TUR is incomplete or provokes recurrence in a high \%age of patients. ${ }^{(74)}$ Hence it is essential to consider adjuvant therapy in these patients. Early single instillation has been shown to function by the destruction of circulating tumor cells resuloting from TUR and by an chemo resection on residual tumor cells at the resection site and on small overlooked tumors.(84-87) One immediate instillation of chemotherapy after TUR reduces recurrence rate by $11.7 \%$ compared to TUR alone.(88) In low risk patients a single immediate instillation reduces risk of recurrence and is considered standard treatment. ${ }^{(88)}$ Also adapting urinary $\mathrm{pH}$, decreasing urinary excretion and buffering the intravesical solution reduces the recurrence rate.(89)

BCG therapy prevents or at least delays the risk of tumor progression. ${ }^{(90,91)}$ Five meta-analysis have confirmed that BCG after TUR is superior to TUR alone or TUR and chemotherapy for prevention of recurrence of non-muscle-invasive tumors.(92,93-96) BCG instillations are given in 6weekly schedule that was introduced by Morales in 1976.(97) However intravesical BCG therapy is associated with more side effects than with intravesical chemotherapy(98) and BCG should not be administered i) during the first two weeks after TUR, ii)in patient with macroscopic hematuria, iii)after traumatic catheterisation, iv) immune-compromised patients, v) personal history of BCG sepsis and vi) in patients with symptomatic UTI. In non-muscle-invasive tumors, patients may benefit from BCG instillation in cases of recurrence after chemo therapy. Prior intravesical chemotherapy has no impact on effects of BCG therapy. ${ }^{(92)}$

INTERFERON: Interferons are glycoproteins produced in response to antigenic stimuli. Intra-vesical interferon alfa- $2 b$ has been shown to have activity in non-muscle invasive urothelial carcinoma both as monotherapy and most recently in combination with low-dose BCG therapy.(93-97)

\section{INTRAVESICAL CHEMOTHERAPY:}

MITOMYCIN C:Mitomycin C is a 334-KD alkylating agent that inhibits DNA synthesis. The drug is usually instilled weekly for 6 to 8 weeks at the dose ranges from 20-60 mg. Methods to enhance the concentration and activity of mitomycin in urine have been described for improved recurrence free survival and prolonged median time to recurrence.(98) Perioperative mitomycin $\mathrm{C}$ should not be administered patients with known or suspected bladder perforation following TURBT as a small number of serious complications related to mitomycin C extravasation have been reported.(99,100,101) 
DOXORUBICIN AND ITS DERIVATIVES:Doxorubicin (Adriamycin) is a $580 \mathrm{KD}$ anthracycline antibiotic that act by binding DNA base pairs, inhibiting topoisomerase II, and inhibiting protein synthesis. The principal side effect of intravesical doxorubicin is chemical cystitis, which can occur in up to half of the patients. Valrubicin is a semisynthetic analog of doxorubicin that has been approved by the FDA for treatment of BCG refractory CIS in patients who cannot tolerate cystectomy, with modest efficacy observed in this setting.(102)

THIOTEPA: Thiotepa (triethylenethiophosphoramide) is the only chemotherapeutic agent approved by the FDA specifically for the intravesical treatment of papillary bladder cancer.it is an alkylating agent and is not cell cycle specific. The lower dose appeared to be $s$ effective as higher in a comparative study when the concentrations were same.(103)

GEMCITABINE: Systemic gemcitabine in combination with cisplatin has been shown to result in similar survival rates compared to traditional chemotherapy but with over all better patient tolerability and better safety profile.(104)

PHOTODYNAMIC THERAPY: The photodynamic has antitumor effects due to creation of reactive oxygen species that result from activation of a photo-sensitizing agent. The agent is activated by absorbance of wavelengths of light specific for the spectrum of the agent.(105,106) However there very few reports of the success of photodynamic therapy for bladder carcinoma with long term followup. (107,108) $^{-10}$

LASER ABLATION THERAPY: Laser is not optimal for treatment of new bladder lesion as tissue samples are requisite to determine depth of invasion and tumor grade. Appropriate patients for this therapy have papillary, low grade tumors and history of low-grade, low-stage tumors. ${ }^{56)}$

RADICAL CYSTECTOMY FOR NMIBC: Radical cystectomy can be considered in selected patients with NMIBC. It has been shown in retrospective study that cases with high risk NMIBC who undergo early rather than delayed cystectomy for tumor relapse after initial therapy with TURB and BCG have better survival rate.(109)

FOLLOW-UP OF PATIENTS WITH NMIBC: The potential of disease recurrence and progression even in long term typically requires lifelong follow-up. ${ }^{(76,110,111,112)}$ Patients should be assessed every three months in the first two years followed by every six months for another 2-3 years and then annually. $(76,113)$ In high risk tumors it should be done after 3 months for a period of two years and every 6 months there-after.

MANAGEMENT OF INVASIVE AND METASTATIC BLADDER CANCER: Clinical presentation, diagnosis and evaluation are to be done as already described. Bimanual examination is a sensitive and inexpensive method for obtaining evidence of extra vesical extension of bladder cancer. Restaging TUR not only provide information about residual disease, but in patients for whom bladder sparing strategies are contemplated, the reduction of stage to $\mathrm{p} 0$ by second TUR has been associated with favorable long term survival in selected patients. 
RADICAL CYSTECTOMY FOR INVASIVE BLADDER CANCER: Radical cysto-prostatectomy in the male patient which includes complete removal of the bladder and prostate in men and anterior exenteration in the female patient which includes the bladder, uterus and all or part of vagina in women remains the standard surgical approaches to muscle invasive bladder carcinoma.(114)Standard radical cystectomy includes bilateral pelvic lymphadenectomy and, in the male patient, subsequent removal of the prostate and bladder en bloc. In the female patient, anterior exenteration requires removal of the uterus, fallopian tubes, ovaries, bladder, urethra, and a segment of anterior vaginal wall. With radical cystectomy alone, 5 year survival rate with recurrence free survival ranges between $62 \%$ to $68 \% .^{(115,116)}$ Disease specific and overall survival for patients with high-grade UC are closely linked with pathologic disease stage, with 5 year survival dropping to $26 \%$ for men with positive lymph nodes (116). Studies suggest that surgical techniques including extent of lymph node dissection may influence outcomes after radical cystectomy. $(117,118,119)$

Recent experiences with laparoscopic and robotic radical cystectomy and lymphadenectomy have similar morbidities and functional outcomes to open approaches.(120)Despite aggressive and often early intervention, many patients with muscle-invasive $\mathrm{BC}$ treated by surgery alone still remain at considerable risk for recurrence and death from BC.(115)

RADIATION THERAPY: Results of a clinical trial comparing neo-adjuvant radiotherapy before cystectomy to definitive radiotherapy followed by salvage cystectomy for progressive disease with advanced UC were published by Bloom et al.(121) The 10-year cancer-specific mortality ratio was 1.77 in favor of non-adjuvant radiation followed by surgery over the radiation with delayed salvage cystectomy.(121) A nonrandomized study (Skinner et al) for the efficacy of neo-adjuvant radiation before cystectomy with cystectomy alone showed no effect on time to recurrence or overall survival with 1600 rad of radiation given for 4 days prior to surgery.(122)

CHEMOTHERAPY: Despite excellent control with surgery for localized disease, no of patients recue after radical cystectomy alone especially those with advanced disease at the time of diagnosis. Multiple studies have demonstrated the effects of cytotoxic chemotherapy for UC.(123,124) A no of single-agent therapies have demonstrated some efficacy after radical cystectomy.(125,126) With a lack of clear benefit with single agent therapy, combination chemotherapy has also shown to have a more promising effect on BC.(127) Delay of radical cystectomy has been shown to correlate with decreased survival and may mitigate the advantages of neo-adjuvant therapy.(128) In general, patients are more likely to tolerate the effects of chemotherapy before major surgery and any impairment in renal function after surgery may limit the use of certain effective agents and dosages.(129) A retrospective study has shown that adjuvant chemotherapy is independently associated with improved overall survival especially in highest-risk quintile.(130)

BLADDER SPARING THERAPIES: Herr et al described the results of patients with muscle invasive UC choosing to follow their BT after restaging TUR showed either no residual or only superficial disease.(131) After a follow-up of 10 years $76 \%$ patients (75 out of 99) were alive and out of them 57 patients had their bladder intact suggesting that some carefully selected patients with muscle invasive disease could experience long term survival with only local resection. 
METASTATIC AND LOCALLY ADVANCED BLADDER CARCINOMA: Prior to the development of effective chemotherapy median survival with metastatic BC was 3-6 months. Platinum based chemotherapy (Gemcitabine with either cisplatin or carboplatin) may be recommended as initial treatment for patients with advanced invasive urothelial carcinoma.(104) Locally advanced BC (T4b) each case is to be considered individually and initial treatment with combination chemotherapy followed by reassessment and further local measures.

SURVEILANCE: Bladder cancer is a common, heterogeneous disease associated with high rate of recurrence and that often requires lifelong surveillance.(132-135) Treatment options are limited with initial management involving TURBT followed by adjuvant instillations of chemotherapy or immunotherapy to reduce recurrence and prevent disease progression.(133) Each of the intravesical therapy option has associated toxicities that impair patient compliance.(136-140)

Cystoscopy Surveillance Office -based cystoscopy offers rapid, relatively painless visual access to the urothelium. Papillary tumors are readily identified arising from the smooth bladder surface. CIS is classically described as a velvety red mucosal patch. The absence of recurrence on 3month surveillance cystoscopy in patients with TaG1 tumor is associated with recurrence rates so low that annual cystoscopy appears safe even at that point beginning 12 months after initial resection.

URINE CYTOLOGY: urine cytology is not a laboratory test - it is the pathologist's interpretation of the morphologic features of shed urothelial cells. Poor cellular cohesion in high grade tumors, especially CIS, enhances the yield of cytology. It is of very high specificity, is the most important featuring of cytology, because a positive reading regardless of cystoscopy or radiographic findings suggests the existence of malignancy in vast majority of patients. Cytology has very high specificity but has low sensitivity for both low grade tumors, including CIS in recently published reports.

CONCLUSION: An old saying a stitch in time saves nine holds true for bladder cancer. In spite of technological advances in imaging, better understanding of the pathology and much wider availability of instrumentation, the number of cases of bladder cancer have increased. This increase can be attributed to greater awareness of the people towards the disease and the presence of better medical facilities available. Early diagnosis of the disease is the most important prerequisite for a complete cure of the disease. Clinical suspicion and early intervention can indeed halt the disease process because bladder cancer is elusive to imaging at an early stage. Medical centers providing specific care for bladder cancer should educate masses regarding the same so that awareness can spread and the disease are nipped in the bud.

\section{REFERENCES:}

1. Sonny L. Johansson and Samuel. Seminars in surgical oncology. Vol 13 issue 5 pages 291-298 September/October, 1997.

2. Cancer facts and figures 2006.Atlanta: American cancer society 2006.

3. Ries LA, Eisner M P, Kosary CL, Hankey BF, Miller BA, Clegg L et al: SEER cancer statistics review, 1975-2000.Bethesda: National cancer Institute, 2003.

4. Cancer facts and figures 2007.Atlanta: American cancer society 2007. 
5. National cancer institute. Cancer topics. Bladder cancer, http://www.cancer.gov/.Accessed April 2007.

6. Rehn L: Blasengeschwulstebei Fuchsin-Arbeitern. Arch KlinChir 1895; 50: 588.

7. Choi JY, Lee KM, Cho SH, Kim SW, Cho HY, Lee SY et al:CYP2E1 and NQ01 genotypes, smoking and bladder cancer. Pharmacogenetics 2003; 13: 349.

8. Engel LS, Taioli E, Pfeifer R, Garcia-Closas M, Marcus PM, Lan Q et al: Pooled analysis and metaanalysis of glutathione S-transferase M1 and bladder cancer: a HuGE review. Am J Epidemiol 2002; 156: 95.

9. Marcus PM, Vinesis P and Rothman N: NAT2 slow acetylation and bladder cancer risk: a metaanalysis of 22 case-control studies conducted in general population. Pharmacogenetics 2000; 10: 115.

10. Hazra A, Gu J and Wu X: Genetics susceptibility to bladder cancer.In: Text book of bladder cancer. Edited by SP Lerner, MP Schoenberg and CN Sternberg. Oxford: Taylor and Francis 2006; pp 2-36.

11. Theodorescu D: Molecular pathogenesis of proliferative and progressive (invasive) urothelial cancer. In: Urothelialtumors. Edited by MJ Droller, K Goldsmith and C goldsmith. Hamilton: BC Decker 2004; pp28-43.

12. Esrig D, Elmajian D, Groshen S, Freeman JA, Stein JP, Chen SC et al: Accumulation of nuclear p53 and tumor progression in bladder cancer. N Engl J Med 1994; 331: 1259.

13. Cordon-Cardo C, Zhang ZF, dalbangi G, Drobnjak M, Charytonowicz E, Hu SX et al: Cooperative effects of p53 and pR Balterationsin primary superficial bladder tumors. Cancer Res 1997; 57: 1217.

14. Grossman HB, Liebert M, Antelo M, Dinney CP, Hu SX, Palmer JL et al: p53 and RB expression predict progression in T1 bladder cancer. Clin Cancer Res 1998, 4: 829.

15. Malats N, Bustos A, Nascimento CM, Fernandez F, Rivas M, Puente D et al: P53 as a prognostic marker for bladder cancer: a meta-analysis and review. Lancetn Oncol 2005; 6: 678.

16. Burger M, Catto JW, Dalbangi G, et al. Epidemiology and risk factors of urothelial bladder cancer. Eur Urol 2013 Feb; 63 (2): 234-41.

17. Rafnar T, Vermeulen SH, Sulem P, et al. European genome-wide association study identifies SLC14A1 as a new urinary bladder cancer susceptibility gene. Hum Mol Genet 2011 Nov 1; 20 (21): 4268-81.

18. Freedman ND, Silverman DT, Hollenbeck AR, et al. Association between smoking and risk of bladder cancer among men and women. JAMA 2011 Aug 17; 306 (7): 737-45.

19. Rushton L, Bagga S, Bevan R, et al. Occupation and cancer in Britain. Br J Cancer 2010 Apr 27; 102 (9): 1428-37.

20. Rushton L, Hucthings SL, Fortunato L, et al. occupational cancer burden in Great Britain. BR J Cancer 2012 Jun 19; 107 suppl 1: S3-S7.

21. Samanic CM, Kogevinas M, Silverman DT, et al. Occupation and bladder cancer in a hospital based case-control study in Spain. Occup Environ Med 2008 May; 65 (5): 347-53.

22. Ros MM, Bas Bueno-de-Mesquita HB, Buchner FL, et al. Fluid intake and the risk of urothelial cell carcinomas in the European Prospective Investigation into cancer and nutrition (EPIC). Int J cancer 2011 Jun 1; 128 (11): 2695-708.

23. Millan-Rodriguez F, Chechile-Toniolo G, Salvador-Bayarri J, et al. Primary superficial bladder cancer risk groups according to progression. J Urol 2000; 164 (3 Pt 1): 680-4. 
24. Montironi R, Lopez-Beltran A. The 2004 WHO classification of bladder tumors: a summary and commentary. Int J SurgPathol 2005; 13 (2): 143-53.

25. Oosterhuis JW, Schapers RF, Janssen-Heijnen ML, et al. Histological grading of papillary urothelial carcinoma of the bladder: prognostic. J ClinPathol 2002; 55 (12): 900-5.

26. Montironi R, Mazzucchelli R, Scarpelli M. Precancerous lesions and conditions of the prostate: from morphological and. Ann N Y Acad Sci2002; 963: 169-84.

27. Holmang $\mathrm{S}$, Andius $\mathrm{P}$, Hedelin $\mathrm{H}$, et al. Stage progression in Ta papillary urothelialtumors: relationship to grade. J Urol 2001; 165 (4): 1124-8; discussion 1128-30.

28. Fleshner NE, Herr HW, Stewart Ak, Murphy GP, Mettlin C and Menck HR: The national Cancer Data base report on bladder carcinoma. The American college of surgeons Commission on cancer and the American cancer society. Cancer 1996; 78: 1505.

29. Golin AL and Howard RS: Asymtomatic microscopic haematuria. J Urol 1980; 124: 389.

30. Mohr DN, Offord KP, Owen RA and Melton L J 3rd: Asymptomatic micro hematuria and urologic disease. A population based study. JAMA 1986; 256: 224.

31. Messing E M and Vaillancourt A: Hematuria screening for bladder cancer. J occup Med 1990; 32: 838. Lokeshwe.

32. Asymptomatic microscopic hematuria in adults: summary of the AUA Best practice policy recommendations. September 4, 2007.

33. Smith JA Jr, Labasky RF, Cockett AT, Fracchia JA, Montie JE and Rowland RG: Bladder cancer clinical guidelines panel summary report on management of nonmuscle invasive bladder cancer (stages Ta, T1 and Tis). J Urol 1999; 162: 1697.

34. Tetu B. Diagnosis of urothelial carcinoma from urine. Mod Pathol 2009 Jun; 22 Suppl 2: S53-9.

35. Raitenen M-P, Aine R, Rintala E et al; Finn Bladder Goup. Differences between local and review urinary cytology and diagnosis of bladder cancer. An inter observer multi Centre analysis. Eur Urol 2002; 41(3): 284-9.

36. Lokeshwar VB, Habuchi T, Grossman HB, et al. Bladder tumor markers beyond cytology: international consensus panel on bladder tumormarkers. Urology 2005; 66 (6 suppl1): 35-63.

37. Gias AS, Roos D, DeutekomM,et al. Tumour markers in the diagnosis primary bladder cancer. A systematic review. J urol 2003 Jun; 169 (6): 1975-82.

38. Lotan Y, Roehrborn CG. Sensitivity and specificity of commonly available bladder tumour markers versus cytology: results of a comprehensive literature review and meta-analysis. Urology 2003 jan; 61 (1): 109-18.

39. Van Rhijn BW, van der Poel H G, van der Kwast TH. Urine markers for bladder cancer surveillance: a systematic review. Eur 2005 Jun; 47(6): 736-48.

40. Vrooman OPJ, Witjes JA. Urinary markers in bladder cancer. EurUrol 2008 May; 53 (5): 909-16.

41. Lotan Y, Shariat SF, Schmitz-Drager BJ, et al. Consideration on implementing diagnostic markers into clinical decision making in bladder cancer. Urol Oncol 2010 Jul-Aug; 28 (4): 441-8.

42. Van Rhijn BWG, vanderpoel HG, vander K wast HG. Cytology and urinary markers for the diagnosis of bladder cancer. Eur Urol Suppl 2009; 8: 536-41.

43. Gaston KE and Pruthi RS: Value of urinary cytology in the diagnosis and management of urinary tract malignancies. Urology 2004; 63: 1009.

44. Konety BR: Molecular markers in bladder cancer: a critical appraisal. Urol Oncol 2006; 24: 326. 


\section{REVIEW ARTICLE}

45. Van der Aa MN, Steyerberg EW, Bangma C, et al. Cystoscopy revisited as the gold standard for detecting bladder cancer recurrence: diagnostic review bias in the randomized, prospective CEFUB trial. J Urol 2010 Jan; 1831(1): 76-80.

46. Goessl C, Knispel HH, Millar K, et al. Is routine excretory urography neccessary at first diagnosis of bladder cancer? J Urol 1997 Feb; 157 (2): 480-1.

47. Palou J, Rodriguez-Rubio F,Huguet J, et al. Multivariate analysis of clinical parameters of synchronous primary superficial bladder cancer and upper urinary tract tumours. J urol 2005 Sep; 174 (3): 859-61.

48. Holmang S, Hedelin $\mathrm{H}$, Anderstrom $\mathrm{C}$, et al. Long-term follow-up of a bladder carcinoma cohort: routine follow-up urography is not necessary. J Urol 1998 Jul; 160 (1): 45-8.

49. Nolte- Ernsting C, Cowan N. Understanding multislice CT urography techniques: many roads lead to Rome. Eur Radiol 2006 Dec; 16 (12): 2670-86.

50. Kurth KH, Schellhammer PF, Okajima E, et al. Current methods of assessing and treating carcinoma in situ of the bladder with or without involvement of the prostatic urethra. Int J Urol 1995 Jun; 2 (Suppl2): 8-22.

51. Aaronson DS, Walsh TJ, Smith JF, et al. Meta-analysis: does lidocaine gel before flexible cystoscopy provide pain relief? BJU Int 2009 Aug; 104 (4): 506-9; discussion 509-10.

52. Blick CG, Nazir SA, Mallett S, et al. Evaluation of diagnostic stratgies for bladder cancer using computed tomography (CT) urography, flexible cystoscopy and voided urine cytology: results for 778 patients from a hospital haematuria clinic. BJU Int 2012 Jul; 110 (1): 84-94.

53. Zaak D, Karl A, Knuchel R, Stepp H, Harmann A, Reich O et al: Diagnosis of urothelial carcinoma of bladder using flourescence endoscopy. BJU Int 2005; 96: 217.

54. Babjuk M, Soukup V, Oetrik R, Jirsa M and Dvoracek J: 5aminolevulinic acid induced flourescence cystoscopy during transurethral resection reduces the risk of recurrence in stage Ta/T1 bladder cancer. BJU Int 2005; 96: 798.

55. Daniltchenko DI, Riedl CR, Sachs MD, Koenig F, Daha KL, pfleug H et al: Long term benefit of 5aminolevulinic acid flourescence assisted transurethral resection of superficial bladder cancer: 5-year results of of a prospective randomized study. J Urol 2005; 174: 2129.

56. Jocham D, Witjes F, Wagner S, Zeylemaker B, van Moorselaar J, Grimm MO net al: Improved detection and treatment of bladder cancer using hexaminolevulinate imaging: a prospective, phase III multicenter study. J Urol 2005; 174: 862.

57. Shelfo SW, Brady JD and Soloway MS: Transurethral resection of bladder cancer.AtlasUrolClin N A, 1997; 5: 1.

58. Maruniak NA. Takezawa $\mathrm{K}$ and Murphy WM: Accurate pathological staging of urothelial neoplasms requires better cystoscopic sampling. J Urol 2002; 167: 2404.

59. Epstein JI, Amin MB, Reuter VR and Mostofi FK: The world health organisation/international society of urological pathology consensus classification of urothelial (transitional cell) neopasms of urinary bladder. Bladder consensus conference committe. Am J SurgPathol 1998; 22: 1435.

60. HeneyNM, Ahmed S,Flanagan MJ, Frable W,Corder MP, Hafermann MD et al: Superficial bladder cancer: progression and recurrence. J Urol 1983; 130: 1083.

61. Pagano F, Garbelio A, Milani C, Bassi P and Pegoraro V: Prognosis of bladder cancer. I. Risk factors in superficial transitional cell carcinoma. EurUrol 1987; 13:145. 
62. Eble JN, Sauter G, Epstein JI and Sesterhenn IA: World health organisation classification of tumours: Pathology and genetics of tumours of the urinary and male genital organs. Lyon: IARC Press 2004.

63. Dalesio O, Schulman CC, Sylvester R, De Pauw M, Robinson M Denis L et al: Prognostic factors in superficial bladder tumours. A study of the European Organisation for Reasearch on Treatment of Cancer: Genitourinary tract cancer cooperative group. J Urol 1983; 129:730.

64. Sylvester RJ, van der Meeijden AP, Oosterlinck W Witjes JA, Bouffioux C, Denis L et al: Predicting recurrence and progression in individual patients with stage Ta T1 bladder cancer using EORTC risk tables: a compound analysis of 2596 patients from seven EORTC trials. Eur Urol 2006; 49:466.

65. Younes M, Sussman J and True LD: The usefulness of the the level of muscularis mucosae in the staging of invasive transitional cell carcinoma of urinary bladder. Cancer 1990; 66: 543.

66. Hasui Y, Osada Y, Kitada S and Nishi S: Significance of invasion to the muscularis mucosae on progression of superficial bladder cancer. Urology 1994; 43: 782.

67. Smits G, Schaafsma E, Kiemeney L, Caris C, Debruyne F and Witjes JA: Microstaging of pT1 transitional cell carcinoma of bladder: identification of subgroups with distinct risks of progression. Urology 1998; 52:1009.

68. Orsola A, Trias I, RaventosCX,Espanol I, Cecchini L, Bucar S et al: Initial high grade T1 urothelial cell carcinoma: feasibility and prognostic significance of lamniapropria invasion microstaging (T1a/b/c) in BCG -treated and BCG-non-treated patients. EurUrol 2005; 48:231.

69. Bernardini S, Billerey C, Martin M, Adess GL, Waller and H and Bittard H: The Waf predictive value of muscularis invasion and p53 over expression on progression of stage T1 bladder carcinoma. J urol 2001; 165:42.

70. Lopez-Beltran A, Luque RJ, Alvarez-Kindelan J, Quintero A, Merlo F, Requena MJ et al: Prognostic factors in survival of patients with stage Ta and T1 bladder urothelialtumors: the role of G1-S modulators (p53,p21 Walf, p27Kipl,cyclin D3), proliferation index, and clinicopathologic parameters. Am J Clin Pathol 2004; 122: 444.

71. Habuchi T, Marberger M, Droller MJ, Hemstreet GP 3rd, Grossman HB, Schalken JA et al: Prognostic makers for bladder cancer: International Consensus Panel on bladder tumor markers. Urology 2005; 66: 64.

72. Koch MO, and smith JA Jr: Natural history and surgical management of superficial bladder cancer (stage Ta/T1/CIS). In: Comprehensive Textbook of Genitourinary Oncology. Edited by NJ Vogelzang, FM Debruyne, WU Shipley and P Scardino. Baltimore: Lippincott Williams and Wilkins 1996; chap 26, pp 405-415.

73. Richterstetter M, Wullich B, Amann K, et al. The value of extended transurethral resection of bladder tumour (TURBT) in the treatment of bladder cancer. BJU Int 2012 Jul; 110(2 Pt 2): E76-9.

74. Brausi M, Collette L, Kurth K, et al; EORTCGenito-Urinary Tract Cancer Collaborative Group. Variability in the recurrence Rate at first follow-up cystoscopy after TUR in stage Ta T! Transitional cell carcinoma of the bladder: a combined analysis of seven EORTC studies. EurUrol 2002 May; 41(5):523-31.

75. Mariappan P, Zachou A, Grigor KM. Detrusor muscle in the first, apparently complete transurethral resection of bladder tumour specimen is a surrogate marker of resection quality, 
predicts risk of early recurrence, and is dependent on operator experience. EurUrol 2010 May; 57 (5): 843-9.

76. Messing EM and Ctalona W.: Urothelialtumors of the urinary tract. In: Campbell's Urology, 7th ed. Edited by Walsh, AB Retik, ED Vaughan Jr and AJ Wein. Philadelphia: W. B. Saunders 1998; chapt 77, pp 2327-2408.

77. Gupta NP, Nayyar R, Hemal AK, et al. Outcome analysis of robotic pyeloplasty: a large singleCentre experience. BJU Int 2010 Apr; 105 (7): 980-3.

78. Herr HW, Donat SM, Reuter VE. Management of Low Grade Papillary Bladder Tumors. J Urol 2007 Oct; 178 (4 Pt 1): 1201-5.

79. Matzkin H, Soloway MS, Hardeman S. Transional cell carcinoma of prostate. J UROL 1991 Nov; 146 (5): 1207-12

80. Mungan MU, Canda AE, Tuzel E, et al. Risk factors for mucosal prostatic urethral involvement in superficial transitional cell carcinoma of the bladder. Eue Urol 2005 Nov; 48 (5): 760-3.

81. Palou J, Sylvester RJ, Faba OR, et al. Female gender and carcinoma in situ in prostatic urethra are prognostic factors for recurrence, progression, and disease specific mortality in T1G3 bladder cancer patients treated with Bacillus Calmette-Guerin. EurUrol 2012 Jul; 62 (1): 11825.

82. Grimm M O, Steinhoff $\mathrm{Ch}$, Simon $\mathrm{X}$, et al. Effect of routine repeat transurethral resection for superficial bladder cancer: a long-term observation study. J Urol 2003 Aug; 170 (2 Pt 1): 433-7.

83. Divirk RT, Yildirim U, Zorlu F, et al. The effect of repeat transurethral resection on recurrence and progression rates in patients with $\mathrm{T} 1$ tumours of the bladder who received intravesical mitomycin: a prospective, randomized clinical trial. J Urol 2006 May; 175 (5): 1641-4.

84. Soloway MS, Masters S. Urothelial susceptibility to tumor cell implantation: influence of cauterization. Cancer 1980 Sep 1; 46 (5): 1158-63.

85. Pan JS, Slocum HK, Rustum YM, et al. Inhibition of implantation of murine bladder tumor by thiotepa in cauterized bladder. J Urol 1989 Dec; 142 (6): 1589-93.

86. Brocks $\mathrm{CP}$, Buttner $\mathrm{H}$, Bohle A. Inhibition of tumor implantation by intravesical gemcitabine in a murine model of superficial bladder cancer. J Urol 2005 Sep; 174 (3): 1115-8.

87. Oosterlinck W, Kurth KH, Schroder F,et al. A prospective European Organisation for research and Treatment of Cancer Genitourinary Group randomized trial comparing transtransurethral resection followed by a single intravesical instillation of epirubicin or water in single stage Ta, T1 papillary carcinoma of the bladder. J URol 1993 Apr: 149 (4): 749-52.

88. Sylvester RJ, Oosterlinck W, van der Meijden AP. A single immediate post-operative instillation of chemotherapy decreases the risk of recurrence in patients with stage Ta T1 bladder cancer: a meta-analysis of published results of randomized trials clinical trials. J Urol 2004 Jun; 171(6 Pt 1):2186-90.

89. Au JL, Baladament RA, Wientjes MG, et al; International Mitomycin C Consortium. Methods to improve efficacy of intravesical mitomycin C: results of a randomized phase lll trial. J Natl Cancer Inst 2001 Apr; 93 (8): 597-604.

90. Bohle A, Bock PR. Intravesical bacillus Calmette-Guerin versus mitomycin C in supeficial bladder cancer: formal meta-analysis of comparative studies on tumour progression. Urology 2004 Apr; 63 (4): 682-6. Discussion 686-7. 
91. Sylvester RJ, van der Meijden AP, Lammm DL. Intravesical bacillus Calmatte-Guerin reduces the risk of progression in patients with superficial bladder cancer: a meta-analysis of the published results of randomized clinical trials. J rol 2002 Nov; 168 (5): 1964-70.

92. Malmstrom P-U, Sylvester RJ, Crawford DE, et al. An individual patient data meta-analysis of the long term outcome of randomized studies comparing intravesical mitomycin $\mathrm{C}$ versus bacillus Calmette-Guerin for non-muscle invasive bladder cancer. Eur Urol 2009 Aug; 56 (2): 247-56.

93. Shelley MD, Kynaston H, Court J, et al. A systematic review of intravesical bacillus CalmetteGuerin plus transurethral resection vs transurethral resection alone in Ta and T1 bladder cancer. BJU Int 2001 Aug; 88 (3): 209-16.

94. Han RF, Pan JG. Can intravesical bacillus Calmette-Guerin reduce recurrence in patients with superficial bladder cancer? A meta-analysis of randomized trials. Urology 2006 Jun; 67 (6): 1216-23.

95. Shelley MD, Wilt TJ, Court J, et al. Intravesical bacillus Calmette-Guerin is superior to mitomycin $\mathrm{C}$ in reducing tumour recurrence in high risk superficial bladder cancer: a meta-analysis of randomized trials. BJU Int 2004 Mar; 93 (4): 485-90.

96. Bohle A, Jocham D, Bock PR. intravesical bacillus Calmette-Guerin versus mitomycin C for superficial bladder cancer: a formal meta-analysis of comparative studies on recurrence and toxicity. J Urolo 2003 Jan; 169 (1): 90-5.

97. Morales A, Eidinger D, Bruce AW. Intracavitary bacillus Calmette-Guerin in the treatment of superficial bladder tumors. J Urol 1976 Aug; 116(2):180-3.

98. Shang PF, Kwong J, Wang ZP,et al. Intravesical Bacillus Calmette-Guerin versus epirubicin for Ta and T1 bladder cancer. Cochrane Database Syat Rev 2011 May; 11 (5): CD006885.

99. Nieuwenhuijzen JA, Bex A and Horenblas S: Unusual complication after immediate postoperative intravesical mitomycin C instillation. EurUrol 2003; 43: 711.

100. Racioppi M, Porreca A, Foschi N, Delicato G, Destito A and D' Addessi A: Bladder performance: a potential risk of early endovesical chemotherapy with mitomycin C. UrolInt 2005; 75: 373.

101. Cliff AM, Romaniuk CS and Parr NJ: Perivesical inflamation after early mitomycin C instillation. BJU Int 2000; 85: 556.

102. Steinberg G, Bahnson R, Brosman S, Middleton R, Wajsman Z and Wehle M: Efficacy and safety of valrubicin for the treatment of Bacillus Calmette-Guerin refractory carcinoma in situ of the bladder. The Valrubicin Study Group. J Urol 2000; 163: 761.

103. Koontz WW Jr, Prout GR Jr, Smith W, Frable WJ and Minnis JE: The use of intravesical thiotepa in the management of non-invasive carcinoma of the bladder. J Urol 1981; 125: 307.

104. Von der Maase H, Hansen SW, Roberts JT, Dogliotti L, Oliver T, Moore MJ et al: Gemcitabine and cisplatin versus methotrexate, vinblastine, doxirubicin and cisplatin in advanced or metastatic bladder cancer: results of a large, randomized multinational, multicenter, phaselll study. J Clin Oncol 2000; 18: 3068.

105. Nseyo UO: photodynamic therapy. UrolClin North Am 1992; 19: 591.

106. Manyak MJ: Photodynamic therapy: principles and urologic applications. SeminUrol 1991; 9: 192.

107. Hisazumi H, Misaki T and Miyoshi N: Photoradiation therapy of bladder tumors. J Urol 1983; 130: 685 . 
108. Prout GR Jr, Lin CW, Benson R JR, Nseyo UO, Daly JJ, Griffin PP et al: Photodynamic therapy with hematoporphyrin derivative in the treatment of superficial transitional cell carcinoma of the bladder. N Engl J Med 1987; 317: 1251.

109. Herr HW, Sogani PC. Does early cystectomy improve the survival of patients with high risk superficial bladder tumors? J Urol 2001 oct; 166 (4): 1296-9.

110. Donat SM, North A, Dalbagni G and Herr HW: Efficacy of office fulgration for recurrent low grade papillary bladder tumors less than $0.5 \mathrm{~cm}$. J Urol 2004; 171: 636.

111. Cookson MS, Herr HW, Zhang ZF, Soloway S, Sogani PC, and Fair WR: The untreated natural history of high risk superficial bladder cancer: 15 years outcome. J Urol 1997; 158: 62.

112. Leblanc B, Duclos AJ, Benard F, Cote J, Valiquette L, Paquin JM et al: Long-term followup of initial Ta grade 1 transitional cell carcinoma of the bladder. J Urol 1999; 162: 1946.

113. Sengupta $S$ and Blute ML: The management of superficial transitional cell carcinoma of the bladder. Urology 2006; 67: 48.

114. Stein JP, Skinner DG. Srgical atlas. Radical cystectomy. BJU Int. 2004; 94 (1): 197-221.

115. Stein JP, Lieskovsky G, Cote R, et al. Radical cystectomy in the treatment of invasive bladder cancer: long-term results in 1054 patients. J Clin Oncol.2001; 19 (3): 666-675.

116. Madersbacher S, Hochreiter W, Burkhard F, et al.Radical cystectomy for bladder cancer today- a homogeneous series without neoadjuvant therapy. J ClinOncol. 2003; 21 (4): 690-696.

117. Leissner J, Hohenfellner R, Thuroff JW, Wolf HK. Lymphadenectomy in patients with transitional cell carcinoma of urinary bladder; significance of staging and prognosis. BJU Int.2000; 85: 70: 817-823.

118. Koppie TM, Vickers AJ,Vora K, Dalbagni G, Bochner BH. Standardization of pelvic lymphadenectomy performed at radical cystectomy: can we establish a minimum number of lymph nodes that should be removed? Cancer. 2006; 107 (10) 2368-2374.

119. Herr H, Lee C, Chang S, Lerner S. Standardization of radical cystectomy and pelvic lymph node dissection for bladder cancer: a collaborative group report. J Urol. 171 (5): 823-1828. Discussion 1827-1828 (2004).

120. Styn NR, Montgomery.jS, Wood DP, et al. Matched comparison of robotic-assisted and open radical cystectomy. Urology. 2012; 79 (6): 1303-1309.

121. Bloom HJ, Hendry WF, Wallace DM, Skeet RG. Treatment of T3 bladder cancer: controlled trial of preoperative radiotherapy and radical cystectomy versus radical radiotherapy.Br J urol. 1982; 54: (2): 136-151.

122. Skinner DG, Lieskovsky G. Contemprary cystectomy with pelvic node dissection compared to preoperative radiation therapy plus cystectomy in management of invasive bladder cancer. J Urol. 1984; 131 (6): 1069-1072.

123. Wallace DM, Raghavan D, Kelly KA, et al. Neo-adjuvant (pre-emotive) cisplatin therapy in invasive transitional cell carcinoma of the bladder. Br J Urol. 1991; 6796: 608-615.

124. Coppin CM, Gospodarowicz MK, James K, et al. improved local control of invasive bladder cancer by concurrent cisplatin and preoperative or definitive radiation. The National Institute of Canada Clinical Trials Group. jClinOncol. 1996; 14 (11); 2901-2907.

125. Nanus DM, Bosl GJ. Systemic chemotherapy in management of bladder cancer. Cancer Treat Res. 1989; 46: 143-158.

126. Scher H, Herr H, Sternberg C, et al. Neo-adjuvant chemotherapy for invasive bladder cancer. Experience eith M-VAC regimen. Br J Urol.1989; 64 (3): 250-256. 


\section{REVIEW ARTICLE}

127. Rintala E, Hannisdahl E, Fossa SD, Hellsten S, Sander S. Neoadjuvant chemotherapy in cancer: a randomized study. Nordic Cystectomy Trial I. Scand J UrolNephrol. 1993; 27 (3): 355-362.

128. Lee CT, Madii R, Daignault S, et al. Cystectomy delay more than 3 months from initial bladder cancer diagnosis results in decreased disease specific and overall survival. J Urol. 2006; 175 (4): 1262-1267. Discussion 1267.

129. Millikan R, Dinney C, Swanson D, et al. Integrated therapy for locally advanced bladder cancer: final report of a randomized trial of cystectomy plus adjuvant M-VAC versus cystectomy with both preoperative and postoperative M-VAC. J Clin Oncol.2001; 19 (20): 4005-4013.

130. Svatek RS, Shariat SF, Lasky RE, et al. The effectiveness of off-protocol adjuvant chemotherapy for patients with urothelial carcinoma of the urinary bladder. Clin Cancer Res. 2010; 16 (17): 4461-4467.

131. Herr HW. Transurethral resecrin of muscle-invasive bladder cancer: 10-year outcome. J ClinOncol. 2001; 19 (1): 89-93.

132. A. Jemal, R. Siegel, J. Xu, and E. Ward," Cancer Statistics, 2010, "CA Cancer Journal for clinicians, vol.60, no.5, pp.277-300, 2010.

133. E.B.C. Avritscher, C.D. Cooksley, H.B.Grossman et al.," Clinical model of lifetime cost of treating bladder cancer and associated complications," Urology, vol.68. no.3, pp.549-553, 2006.

134. J.A. Witjes and K. Handricksen,"Intravesical pharmacotherapy for non-muscle-invasive bladder cancer: a critical analysis of currently available drugs, treatment schedule, and long-term results," European Urology, vol.53, no.1, pp.45-52, 2008.

135. C.L. Pashos, M.F. Botterman, B.L. Laskin, and A. Redaelli, "Bladder Cancer: epidemiology, diagnosis, and management," Cancer Practice, vol.10, no.6, pp.311-322, 2002.

136. M.P. Koya, M.A. Simon, and M.S. Soloway,"Complications of intravesical therapy for urothelial cancer of the bladder," Journal of Urology, vol.175, no.6, pp.2004-2010, 2006.

137. K.L Kilbridge and P. Kantoff,"Intravesical therapy for superficial bladder cancer: is it a wash?" Jornal of Clinical Oncology, vol. 12, no.1, pp.1-4, 1994.

138. A. M. Kamat and D. L. Lamm, "Intravesical therapy for bladder cancer," Urology, vol.55, no.2, pp.161-168, 2000.

139. D. L. Lamm, B. A. Blumenstein, J. D. Crissman et al., "Maintainance bacillus Calmette-Guerin immunitherapy for recurrent Ta,T1 and carcinoma in situ transitional cell carcinoma of the bladder:a randomized Southwest Oncology Group Study," Journal of Urology, vol.163, no.4, pp1124-1129, 2000.

140. M. Colombel, F. Saint, D. Chopin, B. Malavaud, L. Nicolas, and P. Rischmann, "The effect of ofloxacin on bacillus Calmette-Guerin induced toxicity in patients with superficial bladder cancer: results of a randomized prospective, doble-blind, placebo controlled, multicenter study," Journal of Urology, vol.176, no.3, pp.935-939, 2006. 


\section{REVIEW ARTICLE}

\section{AUTHORS:}

1. Gurinderjit Singh Nagi

2. Yatin Ghosh

\section{PARTICULARS OF CONTRIBUTORS:}

1. Assistant Professor, Department of Surgery, Punjab Institute of Medical Sciences, Jalandhar.

2. Associate Professor, Department of Surgery, Punjab Institute of Medical Sciences, Jalandhar.

\section{NAME ADDRESS EMAIL ID OF THE} CORRESPONDING AUTHOR:

Dr. Gurinderjit Singh Nagi,

Assistant Professor,

Department of Surgery,

PIMS Medical College,

Jalandhar.

E-mail: nagigurinder@gmail.com

Date of Submission: 16/12/2014.

Date of Peer Review: 17/12/2014.

Date of Acceptance: 23/12/2014.

Date of Publishing: 31/12/2014. 